UDC 378.147.227

Oleksandr S. Lahodynskyi

Doctor of Pedagogical Sciences, Professor, Chief of Foreign Languages Department, Military Diplomatic Academy named after Yevheniy Bereznyak, Kyiv, Ukraine ORCID 0000-0002-8231-3072

berezan2016@meta.ua

Oleksiy V. Buyalo

$\mathrm{PhD}$ in Engineering Sciences, Senior Research Fellow, Associate Professor of Special Disciplines Department, Military Diplomatic Academy named after Yevheniy Bereznyak, Kyiv, Ukraine

ORCID 0000-0002-8848-864x

son2@protonmail.com

Serhiy V. Khamula

$\mathrm{PhD}$ in Engineering Sciences, Associate Professor, Chief of Special Disciplines Department,

Military Diplomatic Academy named after Yevheniy Bereznyak, Kyiv, Ukraine

ORCID 0000-0002-0825-7674

solidniy@meta.ua

\title{
APPLICATION OF ACHIEVEMENT TESTING SOFTWARE OF CADETS IN HIGHER MILITARY EDUCATIONAL INSTITUTIONS
}

\begin{abstract}
The article presents description, advantages, and use of the Achievement Testing Software (ATS) developed by the authors - the teaching staff of the Military Diplomatic Academy named after Yevheniy Bereznyak - for cadets' achievement testing in the educational process of higher military educational institutions. The authors prove the necessity of the ATS introduction into the educational process of such institutions due to the inability of existing computer testing software to fully satisfy their needs (high costs of technical maintenance, closed exit codes, and constant reliance on the Internet connection making it impossible to provide sensitive information security).

Unlike other systems, the ATS is a reliable instrument of military educational control, capable of operating off-line. It was developed based on fundamental works in test theory, measurement and evaluation by Ukrainian and foreign scholars. It can be widely used for different types of achievement testing in higher military educational institutions: classroom; entrance or summative; and in any type of military course. The ATS rational use allows saving learning time and teachers' effort, simultaneous engagement of many cadets in the training process, as well as objective measurement and evaluation through its automation. The ATS also provides capabilities of control over the educational process which allow curricula correction due to the constant feedback from cadets.

Basically, the ATS performs two interrelated functions: test development and editing (by teachers); and academic achievement measuring (by cadets through the developed test items). The system can be easily installed on personal computers with Windows XP Professional SP2 operational system.

The article describes in greater detail the procedure of operating in two modules: the Teacher's Module and the Testing Module. Here, the ATS provides a user-friendly menu that can be easily navigated by pressing on buttons and selecting necessary options according to the instructions. The test entrance is password-protected, the test is encrypted, and the test score can be quickly viewed by cadets and teachers immediately after its completion.

The ATS efficiency was proved through an experiment involving cadets of the Military Diplomatic Academy named after Yevheniy Bereznyak by demonstrating improvement in their performance.
\end{abstract}

Keywords: achievement testing software; higher military educational institutions; education quality; test items development; teacher's module; testing module 


\section{INTRODUCTION}

The problem statement. The problem of ensuring quality of education in higher military educational institutions of Ukraine has lately been recognized as one of the most acute due to several factors:

Firstly, the increased requirements to the would-be military specialists on the part of the customers (military elements and units) operating, virtually, in a high-risk environment of constant hybrid aggression from the Russian Federation;

Secondly, Ukraine's ambition to join NATO in the near future - the regional security organization requiring a high level of specialist training and education in various areas of military, as well as military-civilian affairs;

Thirdly, military educational institutions are part of the public system of higher education, which is currently revising the philosophy of higher education and ensuring its quality, introducing and implementing the best European practices and procedures.

Therefore, cadets' achievement testing is a significant part of the educational process in higher military educational institutions. It aims at providing a feedback on the training which helps to establish the would-be military specialists' readiness to perform professional functions, and, in many ways, to modify and improve the courses. Unfortunately, the current system of such testing is long way from being fair and objective, since teaching personnel is simultaneously engaged in teaching certain courses, compiling test items, directly administering tests and evaluating their score.

Therefore, computer-based achievement testing can be a good solution of this problem. Less personal involvement in this process gives more opportunities for objectivity of test score. This type of testing, though, requires well-developed software which is the product of many years of highly-skilled hard work of both teachers and test developers.

Analysis of recent studies and publications. The problem of computer testing is based on fundamental works in test theory, measurement and evaluation, test construction and test items writing in the area of pedagogy and psychology by L. Crocker, J. Algina [1], N. Campbell [2], R. Linn [3], R. Gale, T. Haladyna [4], N. Gronlund [5].

Methods of using computer testing were researched by L. Morska [6]. She provides a comprehensive analysis of the notion 'computer testing' in the scientific literature, offers a classification of computer tests, studies psychological peculiarities of computer testing, describes a model of developing computer test items and defines requirements to computer test items.

H. Madsen' work is devoted to the presentation and exemplification of practical testing techniques which can also be used in developing computer testing [7]. I. Pietukhova analyzes historic and present-day systems of testing in Ukraine [8]. The monograph largely focuses on comparison of procedures, forms and practices of testing in today's system as well as in the past.

T. Bloom, T. Rich, S. Olson, M. Adams thoroughly study and evaluate students' and teachers' perceptions of the transition to the computer-based testing format in educational process [9]. H. Sari, H. Yahsi Sari, A. Huggins Manley closely study the characteristics of a relatively new type of testing - Computer Adaptive Multistage Testing - including its working principle, adaptation procedure (routing method), test assembly, and scoring. They provide an overview for the researchers, encouraging work in this area [10]. A useful study in the field of designing computerized adaptive tests in the absence of testing statistics was conducted by V. Bondarenko [11].

Issues related to testing students' educational achievements based on Moodle informative environment in traditional higher education were analyzed by N. Boliubash [12]. I. Bloshchynskyi, O. Halus, I. Pochekalin, D. Taushan describe the use of electronic courseware packages for improving the training of the would-be officers of the State Border Guard Service of Ukraine [13]. They also focus on using computer software for final 
evaluation of the cadets' knowledge. In another article, I. Bloshchynskyi discusses development and use of Anki specialized program application for cadets' independent preparation for state examinations in a foreign language [14].

The use of computer software for achievement testing in higher educational institutions was studied by V. Avanesov [15], V. Fetisov [16], L. Kukhar, V. Serhiyenko [17], etc. They all look at educational and developmental functions of computer testing. According to them, this type of testing system does not fully include the control function. The results provided by the use of computer testing can form an effective strategy for the control over the educational process in higher educational institutions. This approach should become key in training would-be officers, as their answers to the tests can be used by the test developers and teachers for the evaluation of the learning materials, cadets' rating, and, eventually, for the correction of curricula with the purpose of making a reliable system of feedback from all the stakeholders of the educational process.

The article's goal is to feature achievement testing software (ATS) developed by the authors and demonstrate the procedure of its use in the educational process of higher military educational institutions.

\section{THE THEORETICAL BACKGROUNDS}

The ATS development and use can provide both the opportunity to automate teacher's traditional work-consuming control functions and to introduce effective flexible teaching and learning technologies depending on the level of training in the conditions of reduced academic time for certain courses. Basic factors affecting the quality of education in higher military educational establishments can be seen in Fig.1.

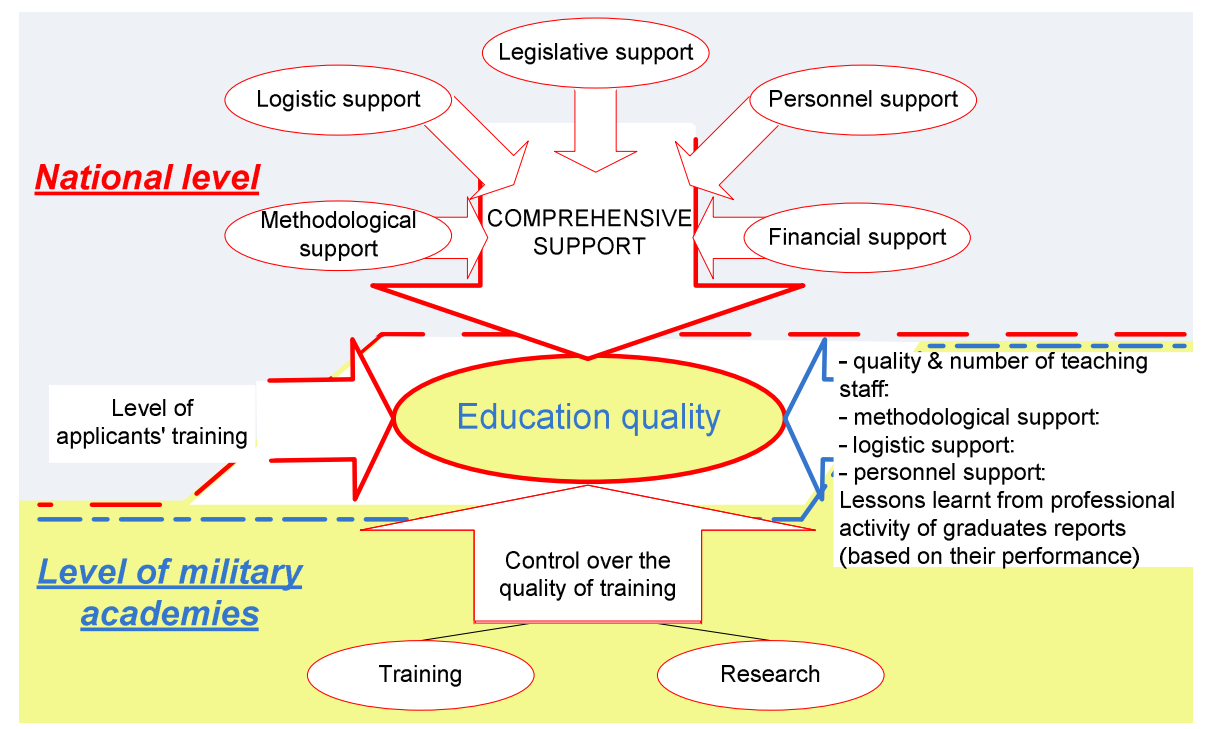

Figure 1. Basic factors affecting education quality in higher military educational institutions

As it can be seen from Fig. 1, at the national level we consider such factors as comprehensive support (legislative, personnel, financial, methodological, and logistic), while at the level of higher military educational establishments the education quality is affected by quality and number of teachers, methodological, logistic, and personnel support. Significant factors are also the level of applicants' training (entrance level), lessons learnt from graduates' job performance annually provided by the customers (military units) as well as control over the quality of training. 
It is necessary to create conditions where exponents affecting the quality of education should be at a level that is not lower than that given in order to provide effective functioning of higher military educational institutions. It can be provided through continuous control, and correction in case of worsening.

ATS can be used as one of the instruments of the education quality control in higher military educational institutions. Use of modern computer technologies in higher education gives an opportunity to upgrade and automate mechanisms of objective control of the training levels as well as to integrate all forms of testing: entrance, class-room, summative etc.

Introduction of ATS gives an option to use learning time effectively and engage all cadets in the process in time-limited conditions. It allows learners to immediately receive their score, and teachers to identify their level of training as objectively as possible. It further gives an opportunity to focus on the most problematic content issues, correct learners' answers and deepen their knowledge on certain topics.

\section{RESEARCH METHODS}

We have used various methods at the theoretical, diagnostic, and empirical levels of our research. At the theoretical level the research methods encompass analysis, synthesis and generalization. At the diagnostic level we used such methods as questionnaires and interviews in order to collect data on the suitability of the existing computer software for achievement testing in higher military educational institutions. At the empirical level an experiment was conducted to prove the ATS efficiency.

\section{THE RESULTS AND DISCUSSION}

\subsection{Analysis of the typical software for meeting achievement testing requirements}

In order to identify which software can meet the requirements of higher military educational institutions for achievement testing, we have conducted questioning and interviews with teaching staff and representatives of military units. The existing software was measured against such features as subject area, training characteristics, commercial peculiarities, country producer, area of use, and technical characteristics. The results on typical software used for this purpose are presented in Fig. 2.

As we can see from Fig. 2, none of the computer software can meet the customers' requirements. Therefore, it can not be fully integrated into the educational process of higher military educational institutions. Here, we can spot the following drawbacks:

Firstly, these types of software are available on commercial or partly-commercial basis with further highly costly technical maintenance;

Secondly, all types of software have a closed exit code which is impossible to open or amend;

Thirdly, it is difficult to provide reliable security for most of the information used in higher educational institutions due to its sensitive nature;

Fourthly, all types of software require periodic or online connection.

All these factors listed above affected the decision to develop our own ATS that would not have these drawbacks. 


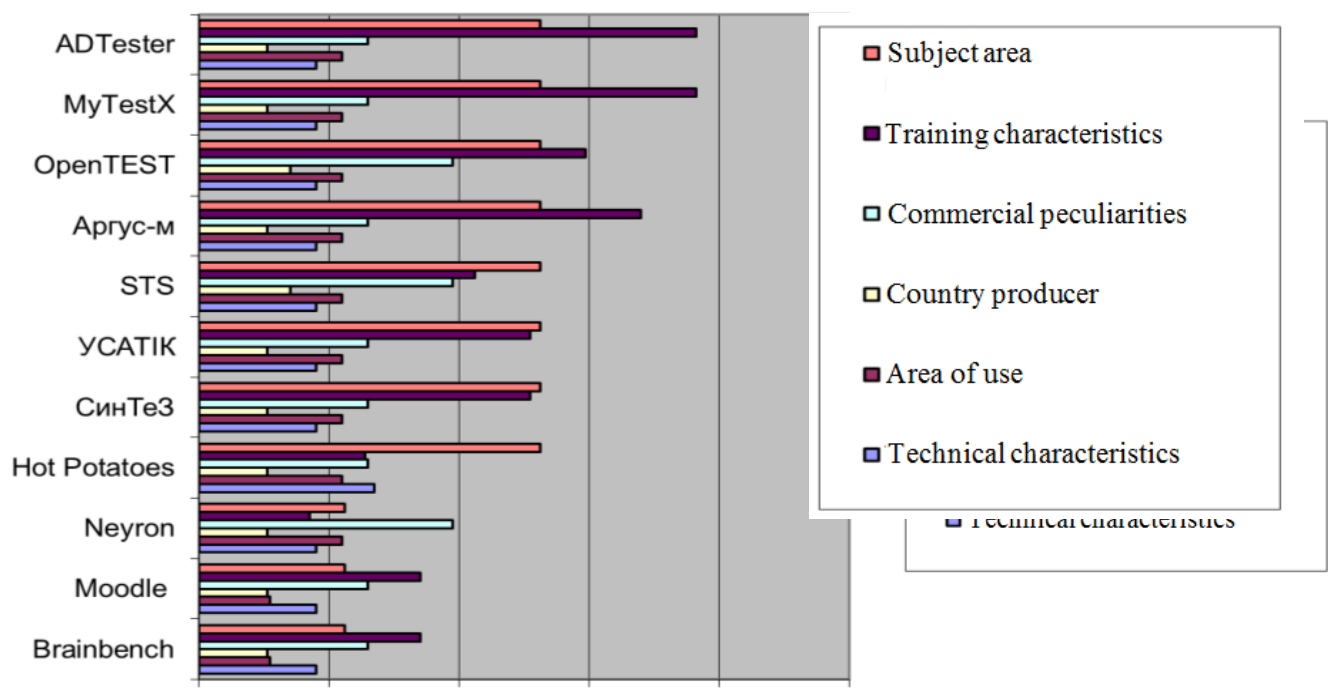

Figure 2. Rating of the typical computer software used for achievement testing

\subsection{ATS description}

The ATS system is designed by the authors of the article for development and editing of test items for the automated measuring of cadets' academic achievement. It can be installed on personal computers with the requirements no lower than the following: Windows XP Professional SP2; MS. NET Framework 3.5; Microsoft Visual Studio 2013;Microsoft SQL CE 4.0; MS .NET Framework 3.5; processor Intel Pentium, Celeron, AMD Athlon, Duron, Sempron with clock rate of $500 \mathrm{MHz}$; RAM of 128 Mbyte; HDD of not less than 20 Gbytes.

Fig. 3 shows the ATS from the teachers' and the learners' perspectives.

It consists of two interrelated modules. The Teacher's module is designed for development and editing of test items while the Testing module aims to identify cadets' level of achievement.

We have also put forward requirements for the modules. For instance, the testing module should be ergonomic, protected, and operational in the local mode (individually on each computer). It also includes a portable version. It also allows the user to select a testing mode. The users need to register in case they are not on the list.

The Teacher's module (on test development) should provide development of a countless number of tests, test items, test versions and forms of answers. It also contains basic functions on text formatting, identifying test weight, and an opportunity to develop basic types of test items as well as password-protection from editing and viewing keys. The module also sets testing time for the whole test and for the individual test items.

The Teacher's module has to provide test score protection, test encryption by means of secure codes; making up users' list; test score analysis of individual learners as well as groups of learners.

Development of test items and their location in the database is quite hard and timeconsuming work that includes search and development of the optimum number of test items capable of meeting pedagogical requirements. The test items should be unambiguous, i.e. cadets (officer students) are not supposed to think about the exact meaning of the information. Test items have to be as brief as possible, i.e. they should take optimum space on the screen (up to 10 words). They should be plausible, i.e. learners can choose or make a logically correct answer. They should also include standard vocabulary avoiding terms which can be interpreted in different ways. Multiple choice test items should include between 4 to 6 options in order to avoid guessing. Each test item should also conform to the thematic field and 
cannot be dependent on other test items. Visually correct answers or keys in multiple choice test items should not be different from other options. Each test version should be balanced, neither complex nor too easy.

The Testing module (for learners) consists of the pools of test batteries on certain courses (subjects). The learners should go through the following stages: identification; test selection; testing mode; testing; and protocol. Each of these stages is user-friendly and provides a score on students' performance in an easy and simple way.

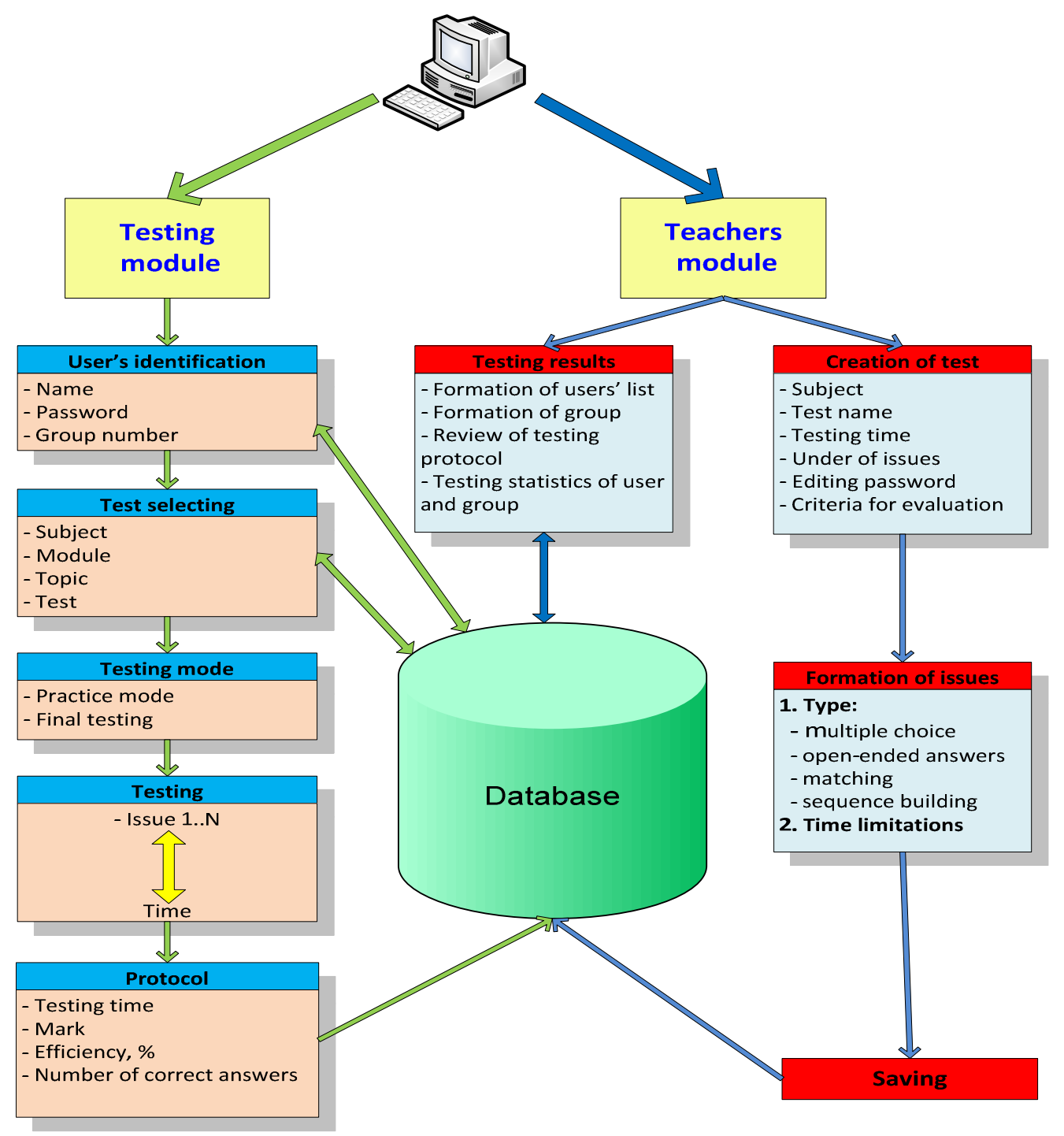

Figure 3. Model of the ATS use

Overall, the ATS can be used for testing basic levels of knowledge before beginning new courses as well as for testing achievement in learning lecture and seminar materials. It can also be used as the entrance test for identifying cadets' readiness for practical or special tactical lessons as well as self-study. It is good as a summative or modular test after a certain topic or module. It can also be used for testing applicants' competencies as the procedure of entering higher military educational institutions. Certain areas of ATS use can be seen in Fig. 4. 


\subsection{The Teacher's module procedure of operation}

This module is designed only for authorized teaching personnel who perform the functions of test developers. In order to launch the program, the test developer should press on Файл button and select Створити option as shown in Fig. 4.

After the successful launch and registration, the test developer should add up a test by pressing on Додати тест button as shown in Fig. 5.

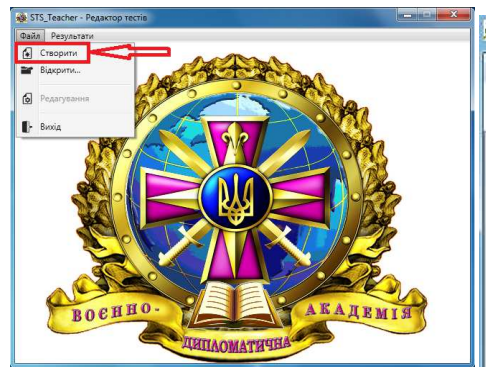

Figure 4. ATS launch

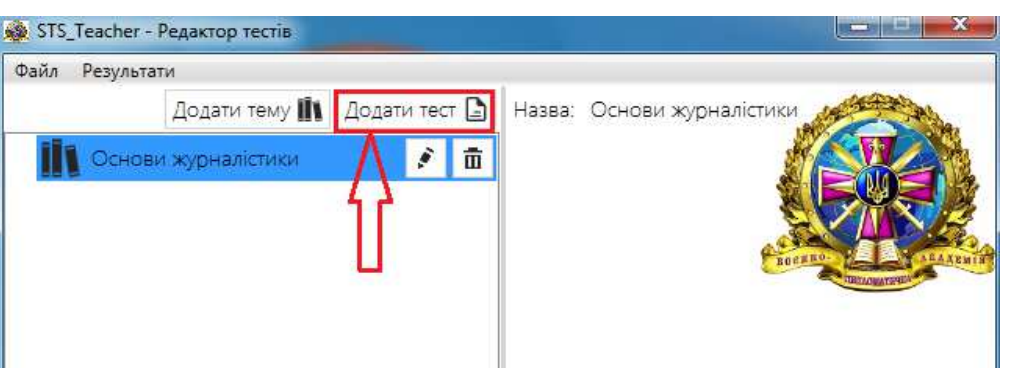

Figure 5. Test add-up procedure

Then the test name, its short description and test time, as well as the number of test items, should be added up in the pop-up window. The next step is adding up test options. Then the developed tests should be saved by pressing on 3берегти button as we can see in Fig. 6.

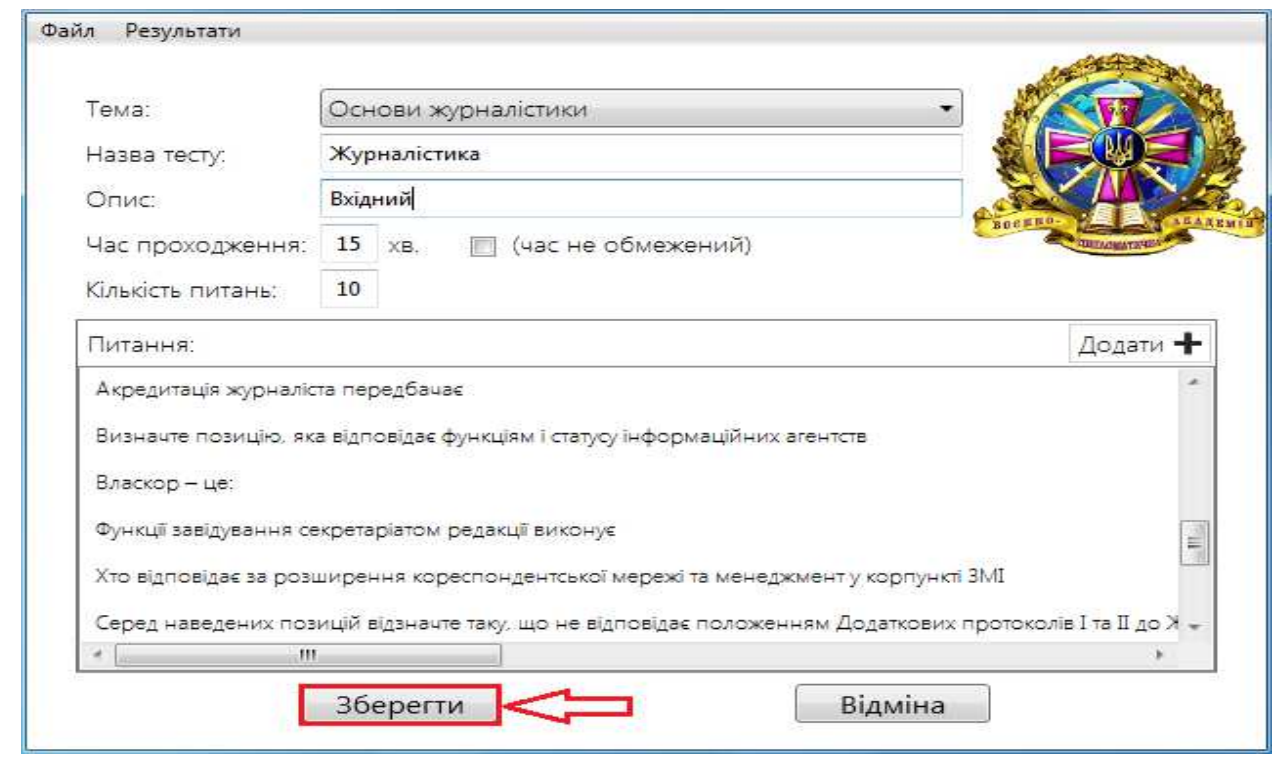

Figure 6. Test saving procedure

After saving the test, it will again pop up in the window including general test description. The test can then be edited. The test score can be viewed by pressing Результати button. The test is exited by pressing on Buхід button. This function is protected by the Ви дійсно хочете покинути тест? window.

\subsection{The Testing module procedure of operation}

Let us take a closer look at the procedure of operation in the Testing module. It is designed for the learners. They have only one option - to perform testing, and have no rights to edit test items. In order to start operation, personal authorization is required. That prevents unauthorized users entering the system. 
Before starting the testing procedure, test specification is provided, including information about the topic of the test, the training module it is based on, the test developer, test format, and timed allocated for the answer.

The learner should start the testing procedure by selecting the course, the test battery, and, finally, press on Розпочати тест button as shown in Fig. 8.

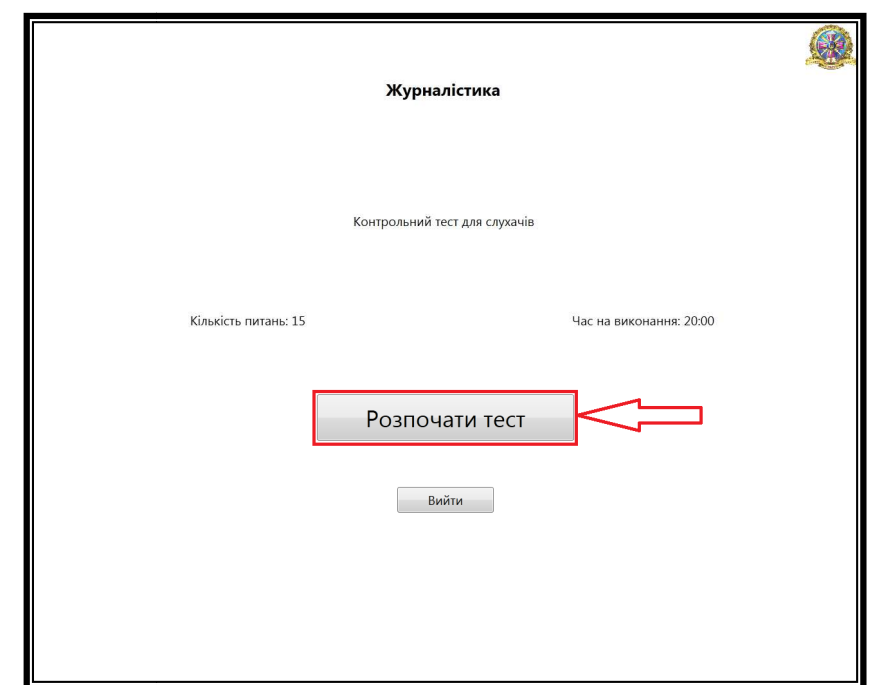

Figure 7. Test start

The test starts by selecting correct answers from the options being proposed. Each test item is time-limited; time limits are set by test developers individually depending on the test specification. In order to move forward, Далi button should be pressed (Fig. 8).

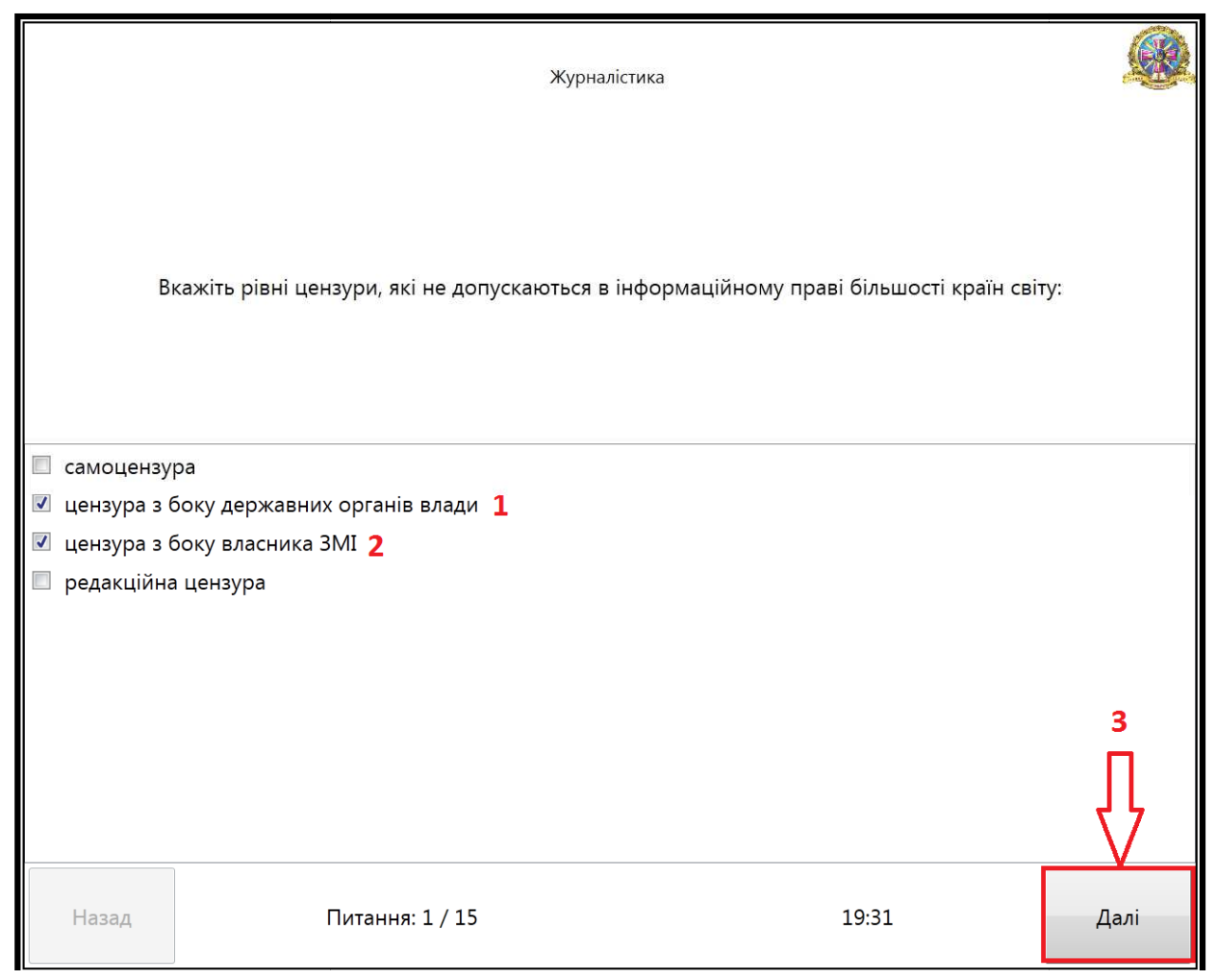

Figure 8. Performing the test 
The system is capable of selecting test items randomly. Testing ends with the last answer to the test item or when the time is up. The test score can be seen on the screen before selecting the Buхid button. In order to view the test score, Результати button should be pressed (Fig. 9)

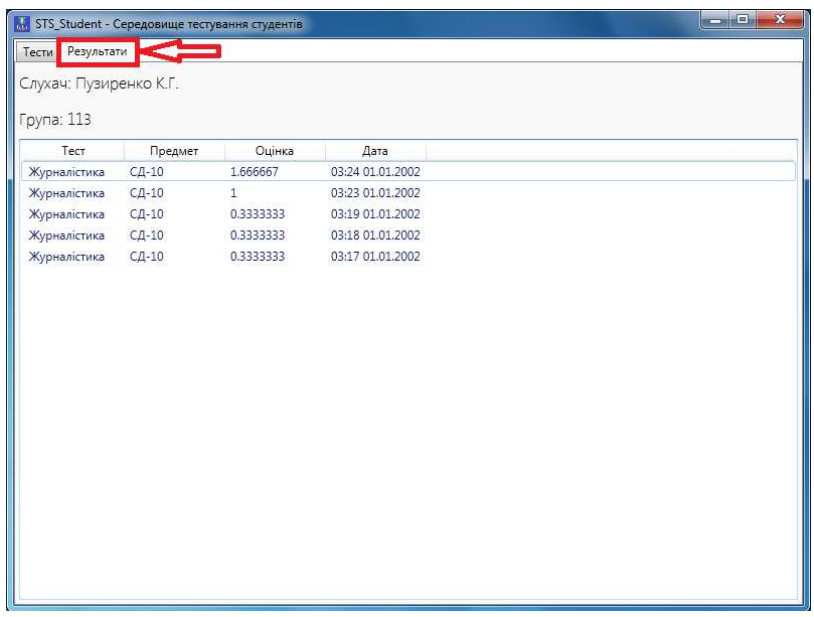

Figure 9. Viewing the test score

Overall, the Testing module is easy to enter and navigate by following the instructions.

\subsection{Experiment on ATS efficiency}

In order to prove the ATS efficiency, an experiment was conducted in the Military Diplomatic Academy named after Yevheniy Bereznyak with the involvement of 78 cadets of the 2015 year of entrance (control group) and the 2017 year of entrance (experimental group). It was based on module 6 The comprehensive employment of the technical devices of the course "Use of technical devices".

The cadets in the control group used the traditional form of training, including theoretical material learning, entrance testing at the beginning of practical or special tactical lessons (pen-and-paper testing).

The cadets in the experimental group used the ATS in classroom training as well as in self-study.

The comparative analysis of cadets' performance in the two groups has shown an increase in the experimental group (Fig. 10).
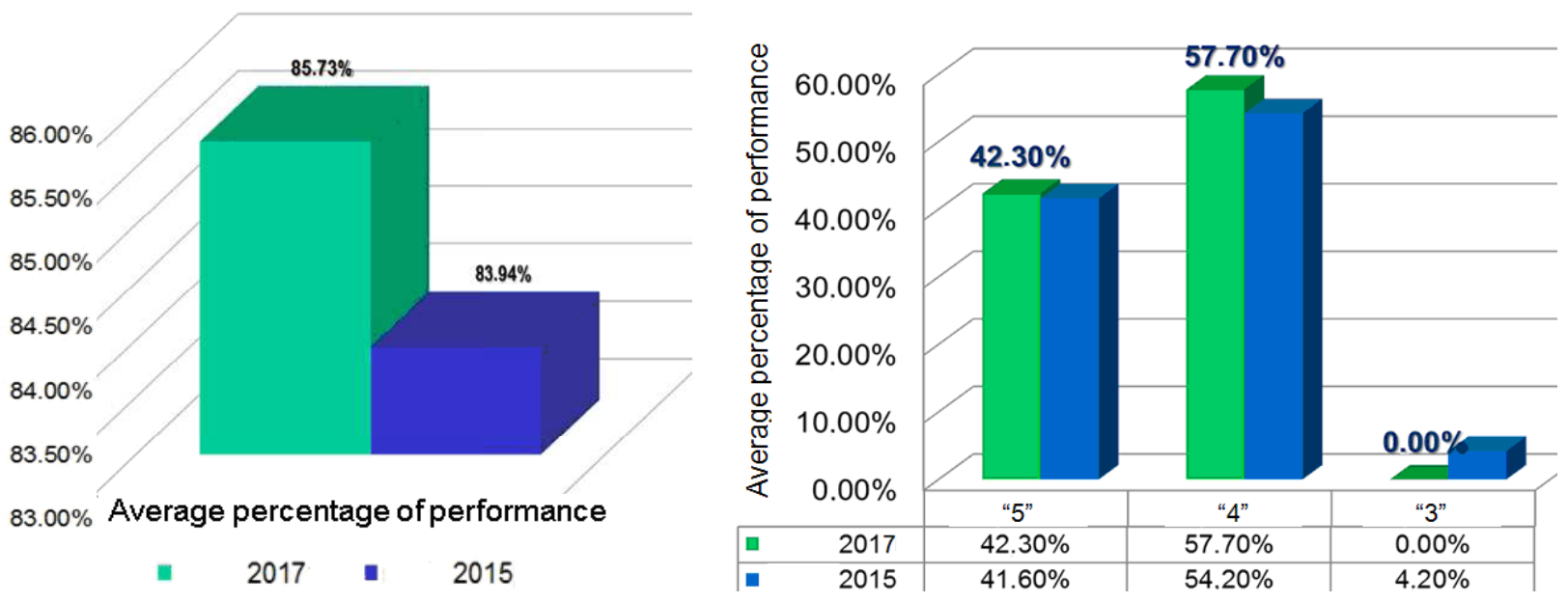

Figure 10. Comparative analysis of cadets' performance in two groups 
As we can see from Fig.10, the number of cadets with an excellent test score is equal in the two groups, while the number of those having the " 4 " mark is higher in the experimental group (the difference is $3.50 \%$ ). The improvement is observed due to the opportunity of the experimental group cadets to use the presented ATS in their self-study. It proved effective and led to the learners' more fundamental acquisition of competencies.

\subsection{ATS implementation in educational process}

Its efficiency proved, the ATS was implemented in the educational process of two military educational institutions: the Military Diplomatic Academy named after Yevheniy Bereznyak (Kyiv) and National Academy of State Border Guard Service of Ukraine named after Bohdan Khmelnytskyi (Khmelnytskyi) at the wide range of military professional and general military courses during years of 2018-2019.

The ATS was primarily used as a summative testing tool at the end of each module to measure cadets' achieved competencies, identified by the syllabi, as well as a part of final examinations. The second area of ATS implementation is the self-studies. It proved to be of great help to the cadets preparing for the final testing as they could practice and get adjusted to the ATS testing procedure. In mid-2019 ATS was used at the entrance exams to the Military Diplomatic Academy named after Yevheniy Bereznyak with the aim of measuring applicants' competencies in tactics and operational arts. Overall, ATS has been implemented 56 times in the educational process since the experiment on its efficiency.

The teaching staff of the above mentioned military educational institutions have developed 34 batteries of various test items for ATS of the following types: multiple-choice ; true/false; open-ended. At the same time, the process of test items development is ongoing.

Although ATS cannot completely substitute face-to-face examinations at the moment, the reviews from teachers and cadets show quite positive feedback on its implementation in the educational process in higher military educational institutions.

\section{CONCLUSIONS AND PROSPECTS FOR FURTHER RESEARCH}

Military education control is a significant function that the computer testing software can provide. Unfortunately, due to high costs, closed exit codes, and inability to provide sensitive information security of existing computer software, it can not be fully integrated into the system of achievement testing in military educational institutions. At the same time, the above described ATS developed by the authors introduces a new philosophy of testing, capable of meeting a maximum of military educational institutions requirements.

ATS is one of the instruments of intensifying the educational process in the context of reducing the academic budget. Use of ATS capabilities sets teachers free from boring and time-consuming work on entrance testing, class testing (before the practical lessons or seminars), and summative testing (at the end of each topic or module). ATS introduction also allows automation of test score, increasing testing process, receiving objective information on each cadet's progress. This system can work off-line, which is crucial to its operation on the courses with sensitive information.

ATS is designed, on the one hand, to construct and edit test items by constantly replenishing the database, and to objectively measure cadets' performance on different types of courses in higher military educational institutions, on the other hand. The ATS functions with two modules: the Teacher's Module and the Testing Module. The system has a userfriendly menu. Both modules are easy to navigate by pressing the buttons and following the instructions. The test items are protected by passwords and encrypted codes. 
The ATS was proved efficient through the experiment involving 78 cadets of the Military Diplomatic Academy named after Yevheniy Bereznyak operating in control and experimental groups by showing an increase in their performance.

In the future it is necessary to develop and upgrade computer test batteries on different military courses. It would also be beneficial to expand the test format by wider introduction of open-ended test items and those with embedded audio- and video files. At the same time, this process requires extensive research support based on the modern science.

\title{
REFERENCES (TRANSLATED AND TRANSLITERATED)
}

[1] L. Crocker, J. Algina, Introduction to Classical and Modern Test Theory. Mason, Ohio, USA: Cengage Learning. 527 p, 2006. (in English).

[2] N. Campbell, An Account of the Principles of Measurement and Calculation. N.Y.: Longmans, Green and Co, Ltd, 293p. 1928. (in English).

[3] R. Linn, Educational Measurement. Washington, DC: American Council on Education, 610 p. 1993. (in English).

[4] R. Gale, T. Haladyna, Technology for Test - Item Writing. N.Y.: Academic Press, 247 p. 1982. (in English).

[5] N. Gronlund, How to Construct an Achievement Test. N.Y.: Prentice-Hall, 148 p. 1982. (in English)

[6] L. Morska, Informational Technologies in Learning Foreign Languages. Ternopil: Aston. 256 p. 2008. (in Ukrainian)

[7] H. Madsen, Techniques in Testing. Oxford: Oxford University Press. 216 p. 1983. (in English).

[8] I. Pietukhova, Testing in Education of Ukraine through the Development of Psycho-pedagogical Science. Irpin: National University of State Tax Service of Ukraine. 197 p. 2014. (in Ukrainian)

[9] T. Bloom, W. Rich, S. Olson, M. Adams, "Perceptions and Performance Using Computer-based Testing: One Institution's Experience", Currents in Pharmacy Teaching and Learning, vol. 10, No 2, pp. 235-242, 2018. doi: 10.1016/j.cptl.2017.10.015 (in English)

[10] H. Sari, H. Yahsi Sari, A. Huggins Manley, "Computer Adaptive Multistage Testing: Practical Issues, Challenges and Principles", Journal of Measurement and Evaluation in Education and Psychology, vol. 7, No 2, pp. 388-406, 2016. doi: 10.21031/epod.280183

[11] V. Bondarenko, "Designing of Computerized Adaptive Tests in the Absence of Testing Statistics", Information Technologies and Learning Tools, vol. $73, \quad$ No $\quad 5, \quad$ pp. $101-115 . \quad 2019$ doi: https://doi.org/10.33407/itlt.v73i5.2520 (in English).

[12] N. Boliubash, "Pedagogical Testing in LMS MOODLE", Information Technologies and Learning Tools, vol. 60, No 4, pp. 116-127. 2017. doi: https://doi.org/10.33407/itlt.v60i4.1726 (in Ukrainian)

[13] I. Bloshchynskyi, O. Halus, I. Pochekalin, D. Taushan, "Use of Electronic Educational and Methodological Software Packages for Improving the Preparation of Future Bachelors of Philology". Information Technologies and Learning Tools, vol. 66., No 4, pp. 101-115. 2019. doi: 10.33407/itlt.v66i4.2327 (in Ukrainian)

[14] I. Bloshchynskyi, "Usage of Anki Specialised Program Application during Future Border Guard officers' Independent Foreign Language Professional Training for Passing State Examination", Information Technologies and Learning Tools, Vol.58, No 2, pp. 105-121. 2017. doi: 10.33407/itlt.v58i2.1605 (in Ukrainian)

[15] V. Avanesov, Composition of Test Items. Moscow, Testing center. 239 p. 2002. (in Russian)

[16] V. Fetisov, Computer technologies in Testing. Nizhyn, PP Lysenko.140 p. 2011. (in Ukrainian)

[17] L. Kukhar, V. Serhiyenko, Test Construction. Lutsk. 182 p. 2010. (in Ukrainian)

Text of the article was accepted by Editorial Team 22.01.2020

\section{ЗАСТОСУВАННЯ ПРОГРАМНОГО ЗАБЕЗПЕЧЕННЯ КОНТРОЛЮ НАВЧАЛЬНИХ ДОСЯГНЕНЬ КУРСАНТІВ У ЗАКЛАДАХ ВИЩОЇ ВІЙСьКОВОї ОСВІТИ}

\author{
Лагодинський Олександр Сергійович \\ доктор педагогічних наук, професор, начальник кафедри іноземних мов \\ Воєнно-дипломатична академія імені Євгенія Березняка, м. Київ, Україна \\ ORCID 0000-0002-8231-3072 \\ berezan2016@meta.ua
}


Буяло Олексій Васильович

кандидат технічних наук, старший науковий співробітник, доцент кафедри спеціальних дисциплін, Воєнно-дипломатична академія імені Євгенія Березняка, м. Київ, Україна

ORCID 0000-0002-8848-864x

son2@protonmail.com

\title{
Хамула Сергій Васильович
}

кандидат технічних наук, доцент, начальник кафедри спеціальних дисциплін, Воєнно-дипломатична академія імені Євгенія Березняка, м. Київ, Україна

ORCID 0000-0002-0825-7674

solidniy@meta.ua

\begin{abstract}
Анотація. У представлені опис, порядок, зазначено переваги використання програмного забезпечення автоматизованого контролю рівня навчальних досягнень, розробленого авторами - науково-педагогічними працівниками Воєнно-дипломатичної академії імені Євгенія Березняка - для тестування рівня навчальних досягнень курсантів в освітньому процесі вищих військових навчальних закладів. Автори доводять необхідність уведення програмного забезпечення автоматизованого контролю рівня навчальних досягнень в освітній процес таких закладів через неможливість наявного на цей час комп'ютерного програмного забезпечення повністю задовольнити їх потреби (великі витрати на технічне обслуговування, закритість вихідних кодів, повна залежність від мережі Інтернет, що унеможливлює забезпечення безпеки конфіденційної інформації).

На відміну від інших систем, розроблене програмне забезпечення автоматизованого контролю рівня навчальних досягнень $є$ надійним інструментом контролю за військовою освітою і здатне працювати без під'єднання до Інтернету. Воно було розроблене на основі фундаментальних праць вітчизняних та зарубіжних науковців 3 теорії тестування, вимірювання і оцінювання навчальних досягнень. Це програмне забезпечення може бути використане в різних видах тестування успішності у вищих військових навчальних закладах (поточного, вступного, підсумкового) та з будь-якого предмета військово-професійної підготовки. Розумне використання програмного забезпечення автоматизованого контролю рівня навчальних досягнень дає можливість зекономити навчальний час та зусилля викладача, одночасно залучити до процесу велику кількість курсантів, а також забезпечити об'єктивне вимірювання і оцінювання знань завдяки автоматизації. Це програмне забезпечення також дає можливості контролю освітнього процесу, що дозволяє корегувати освітні програми завдяки постійному зворотному зв’язку з курсантами.

Програмне забезпечення автоматизованого контролю рівня навчальних досягнень виконує дві основні взаємопов'язані функції: розробку і редагування тестів (функція викладачів) та вимірювання навчальних досягнень (функція курсантів за допомогою розроблених тестових завдань). Програмне забезпечення може легко встановлюватись на персональні комп'ютери 3 операційною системою Windows XP Professional SP2.

У статті досить детально описується порядок роботи з двома модулями: модулем викладача та модулем тестування. Водночас у програмному забезпеченні є зручне для використання меню, яке дає можливість навігації шляхом натискання на кнопки та вибору необхідних опцій відповідно до інструкцій. Вхід до тесту захищений паролем, а сам тест - шифром. Курсанти та викладачі мають можливість швидко переглядати результати тестування одразу ж після завершення тесту. Ефективність застосування програмного забезпечення була підтверджена підвищенням рівня успішності курсантів Воєнно-дипломатичної академії імені Свгенія Березняка, які брали участь в експерименті.
\end{abstract}

Ключові слова: програмне забезпечення автоматизованого контролю рівня навчальних досягнень; вищі військові навчальні заклади; якість освіти; розробка тестових завдань; модуль викладача; модуль тестування.

\section{ПРИМЕНЕНИЕ ПРОГРАММНОГО ОБЕСПЕЧЕНИЯ КОНТРОЛЯ УЧЕБНЫХ ДОСТИЖЕНИЙ КУРСАНТОВ В ЗАВЕДЕНИЯХ ВЫСШЕГО ВОЕННОГО ОБРАЗОВАНИЯ}

\author{
Лагодинский Александр Сергеевич \\ доктор педагогических наук, профессор, начальник кафедры иностранных языков \\ Военно-дипломатическая академия имени Евгения Березняка, г.Киев, Украина \\ ORCID 0000-0002-8231-3072 \\ berezan2016@meta.ua
}


Буяло Алексей Васильевич

кандидат технических наук, страший научный сотрудник, доцент кафедры специальных дисциплин, Военно-дипломатическая академия имени Евгения Березняка, г. Киев, Украина ORCID 0000-0002-8848-864x son2@protonmail.com

\title{
Хамула Сергей Васильевич
}

кандидат технических наук, доцент, начальник кафедры специальных дисциплин, Военно-дипломатическая академия имени Евгения Березняка, г.Киев, Украина ORCID 0000-0002-0825-7674

solidniy@meta.ua

\begin{abstract}
Аннотация. В представлены описание, порядок, указаны преимущества использования программного обеспечения автоматизированного контроля учебных достижений, разработанного авторами - научно-педагогическими работниками Военно-дипломатической академии имени Евгения Березняка - для тестирования уровня учебных достижений курсантов в образовательном процессе высших военных учебных заведений. Авторы доказывают необходимость введения программного обеспечения автоматизированного контроля учебных достижений в образовательный процесс таких заведений из-за невозможности имеющегося в настоящее время компьютерного программного обеспечения полностью удовлетворить их потребности (большие затраты на техническое обслуживание, закрытость исходных кодов, полная зависимость от сети Интернет, что делает невозможным обеспечение безопасности конфиденциальной информации).

В отличии от других систем, разработанное программное обеспечение автоматизированного контроля уровня учебных достижений является надежным инструментом контроля над военным образованием и способно работать без подключения к Интернету. Оно было разработано на основе фундаментальных трудов отечественных и зарубежных ученых по теории тестирования, измерения и оценки учебных достижений. Это программное обеспечение может быть использовано в различных видах тестирования успеваемости в высших военных учебных заведениях (текущего, вступительного, итогового) и по любому предмету военно-профессиональной подготовки. Разумное использование программного обеспечения автоматизированного контроля учебных достижений дает возможность сэкономить учебное время и усилия преподавателя, одновременно привлечь к процессу большое количество курсантов, а также обеспечить объективное измерение и оценивание знаний благодаря автоматизации. Это программное обеспечение также позволяет осуществлять контроль образовательного процесса, корректировать образовательные программы благодаря постоянной обратной связи с курсантами.

Программное обеспечение автоматизированного контроля учебных достижений выполняет две основные взаимосвязанные функции: разработку и редактирование тестов (функция преподавателей) и измерения учебных достижений (функция курсантов с помощью разработанных тестовых заданий). Программное обеспечение может легко устанавливаться на персональные компьютеры с операционной системой Windows XP Professional SP2.

В статье достаточно подробно описывается порядок работы с двумя модулями: модулем преподавателя и модулем тестирования. При этом в программном обеспечении есть удобное для использования меню, которое дает возможность навигации путем нажатия на кнопки и выбора необходимых опций в соответствии с инструкциями. Вход к тесту защищен паролем, а сам тест - шифром. Курсанты и преподаватели имеют возможность быстро просматривать результаты тестирования сразу же после завершения теста. Эффективность применения программного обеспечения была подтверждена повышением уровня успеваемости курсантов Военно-дипломатической академии имени Евгения Березняка, которые принимали участие в эксперименте.
\end{abstract}

Ключевые слова: программное обеспечение автоматизированного контроля учебных достижений; высшие военные учебные заведения; качество образования; разработка тестовых заданий; модуль преподавателя; модуль тестирования.

\section{(cc) BY-NC-SA}

This work is licensed under Creative Commons Attribution-NonCommercial-ShareAlike 4.0 International License. 